\title{
HLA-B Gene Product
}

National Cancer Institute

\section{Source}

National Cancer Institute. HLA-B Gene Product. NCI Thesaurus. Code C128308.

A protein encoded by the HLA-B gene. 